\title{
Comparison of different classes of CpG-ODN in augmenting the generation of human epitope peptide-specific CTLS
}

\author{
MASAHIRO KATSUDA, MAKOTO IWAHASHI, KENJI MATSUDA, MOTOKI MIYAZAWA, MIKIHITO NAKAMORI, \\ MASAKI NAKAMURA, TOSHIYASU OJIMA, TAKESHI IIDA, KEIJI HAYATA and HIROKI YAMAUE
}

Second Department of Surgery, School of Medicine, Wakayama Medical University, Wakayama, Japan

Received January 10, 2011; Accepted March 28, 2011

DOI: $10.3892 /$ ijo.2011.1146

\begin{abstract}
Three distinct classes of $\mathrm{CpG}$-oligonucleotides (ODN) (CpG-A, CpG-B and CpG-C) have been identified on the basis of differences in their structures and immune effects. To date, only CpG-B is applied for clinical treatments; however, it is still unknown which of the different $\mathrm{CpG-ODN}$ classes is most useful as an adjuvant for human cancer vaccine therapy. In the present study, we examined the activity of these 3 types of $\mathrm{CpG}-\mathrm{ODN}$ in enhancing the induction of human peptidespecific CTLs. Our data showed that the specific cytotoxicity was augmented in the presence of $\mathrm{CpG}-\mathrm{A},-\mathrm{B}$ and $-\mathrm{C}$ but not in the presence of control ODN, and the augmenting effect was most potent with $\mathrm{CpG}-\mathrm{A}$. Flow cytometric analysis showed the subpopulation of effector-memory cells in $\mathrm{CD} 8^{+}$cells was most increased with CpG-A. Furthermore, depletion of PDCs from PBMCs before stimulation with peptide and CpG-ODN completely abrogated the augmenting effect of $\mathrm{CpG}-\mathrm{ODN}$. These data indicated that the stimulation of PDCs by CpG-ODN augmented the generation of peptide-specific CTLs, and CpG-A was superior to $\mathrm{CpG}-\mathrm{B}$ and $\mathrm{CpG}-\mathrm{C}$ in terms of augmenting the generation of human peptide-specific CTLs in vitro.
\end{abstract}

\section{Introduction}

The innate immune system is activated via exposure to pathogenassociated molecular patterns (PAMPs) that are expressed by a diverse group of infectious microorganisms. Subsequently, the host mounts an adaptive immune response directed against determinants that are uniquely expressed by the pathogen. The resultant antigen-specific immunity is characterized by the production of high-affinity antibodies and the generation of cytotoxic $\mathrm{T}$ cells that provide long-lasting protection (1).

Correspondence to: Dr Makoto Iwahashi, Second Department of Surgery, School of Medicine, Wakayama Medical University, 811-1 Kimiidera, Wakayama 641-8510, Japan

E-mail: makoto@wakayama-med.ac.jp

Key words: CpG-ODN, peptide vaccine, effector-memory cells
The key feature of innate immune cells that enables them to detect and categorize infection seems to be their repertoire of what have been termed pattern-recognition receptors (PRRs). The best understood family of PRRs is the toll-like receptors (TLRs), of which 10 are known in humans.

In contrast to viruses and other pathogens, vaccines containing recombinant proteins or synthetic antigenic peptides usually fail to induce significant immune responses unless they are mixed with adjuvant $(3,4)$. Because of their high efficacy, several recently identified TLR ligands are promising vaccine adjuvants. Bacterial unmethylated $\mathrm{CpG}$-rich oligodeoxy-nucleotides (ODN), which bind to TLR-9, are one of the most promising candidates for a cancer vaccine adjuvant and are currently being tested in many human clinical trials (5-8).

In numerous murine models, TLR-9 activation enhances antigen-specific cellular responses to a wide variety of antigens. The mechanism that contributes to the potent adjuvant activity of CpG-ODNs is maturation and differentiation of dendritic cells resulting in the strong induction of CTLs, even in the absence of CD4 T-cell help (9). On the other hand, the cellular patterns of TLR expression vary between different species $(2,10)$. B cells, monocytes and all DC subsets express TLR-9 in mice; however, only plasmacytoid dendritic cells (PDC) and B cells express TLR-9 in humans (11-14). Consequently, the murine immune system produces different actions from human systems when exposed to CpG-ODN. Therefore, it is impossible to extrapolate the experimental results from murine models to humans. Furthermore, little is known about the mechanism by which CpG-ODNs augment acquired cellular immunity in humans, although systemically administered CpG-ODNs have shown substantial evidence of augmenting the activity of anti-tumor immunity in human clinical cancer vaccine trials $(5-8)$.

Three distinct classes of CpG-ODN have been identified on the basis of differences in their structures and immunestimulating effects $(9,15-17)$. CpG-A induces the production of high levels of IFN- $\alpha$ from PDC with relatively little B-cell stimulation. In contrast, $\mathrm{CpG}-\mathrm{B}$ induces the production of low levels of IFN- $\alpha$ along with profound B-cell activation. CpG-C has intermediate immune effects with excellent in vivo stability and ease of formation. To date, only $\mathrm{CpG}-\mathrm{B}$ has been applied for clinical treatments; however, the class of $\mathrm{CpG}-\mathrm{ODN}$ 
that is most useful as an adjuvant for a human cancer vaccine is still unknown.

In the present study, we examined the immuno-modulatory activity of these 3 types of $\mathrm{CpG}$ ODN in terms of the generation of peptide-specific CTLs.

\section{Materials and methods}

Cell lines. A24+LCL cells (HLA-A24/24) were a generous gift of Takara Shuzo Co., Ltd. (Otsu, Japan). The A24LCL cells were used for peptide-mediated cytotoxicity assays. These cells were maintained in a tissue culture flask using RPMI and supplemented with antibiotics and 10\% heatinactivated fetal calf serum (Gibco BRL).

Oligodeoxynucleotides. CpG-A was synthesized by Gene Design (Osaka, Japan). CpG-B, CpG-C and GpC-ODN were synthesized by Hokkaido System Science (Sapporo, Japan); CpG-A, 5'-ggTGCATCGATGCAGGGGgg-3'; CpG-B, 5'-tcgtc gtttgtcgttttgtcgtt-3'; CpG-C, 5'-tcgtcgaacgttcgagagatgat-3'; GpC-ODN, the GC control to CpG-ODN, 5'-ggTGCATG CATGCAGGGGgg-3' (lower case letters indicate phosphorothioate linkage; capital letters, phosphodiester linkage $3^{\prime}$ of the base; bold, CpG-dinucleotides).

Peptides. Peptide derived from the squamous cell carcinomaassociated differentiation antigen LY6K-177 (RYCNLEGPPI), influenza (flu) virus-derived peptide (RFYIQMCYEL) and HIV-derived peptide (RYLRDQQLL) with the HLA-A24 binding motif were purchased from Takara Bio Inc. (Otsu, Japan). The purity (>90\%) and the identity of the peptides were determined by analytical HPLC and mass spectrometry analysis, respectively. Peptides were dissolved in dimethylsulfoxide (DMSO) at $20 \mathrm{mg} / \mathrm{ml}$ and stored at $-80^{\circ} \mathrm{C}$.

Cytokine assays. Human PBMCs from healthy volunteers $(n=15)$ were isolated from freshly drawn peripheral blood by Ficoll-Hypaque (Biochrom, Berlin, Germany) density gradient centrifugation. Blood donors were negative for HIV, hepatitis $\mathrm{B}$ virus (HBV) and $\mathrm{HCV}$ infection.

Freshly isolated PBMC $\left(1 \times 10^{6}\right.$ in $500 \mu \mathrm{l}$ of AIM-V media, Invitrogen) were incubated at $37^{\circ} \mathrm{C}$ with $5 \% \mathrm{CO}_{2}$ in 48 -well flat-bottom plates with each class of $\mathrm{CpG}-\mathrm{ODN}$ at different concentrations. Cell supernatants collected after $48 \mathrm{~h}$ were stored at $-80^{\circ} \mathrm{C}$ until assayed. IFN- $\alpha$ in cell supernatants was measured by ELISA according to the manufacturer's instructions (PBL Biomedical Laboratories, Piscataway, USA). All assays were performed in triplicate.

Induction offlu peptide-specific CTLs. For this study, HLA-A24positive donors were selected. PBMCs $\left(2 \times 10^{6} / \mathrm{ml}\right)$ isolated from healthy volunteers were stimulated with the flu peptide at a concentration of $10 \mu \mathrm{g} / \mathrm{ml}$ in the presence of CpG-ODNs (20, 5 and $5 \mu \mathrm{g} / \mathrm{ml}$ for $\mathrm{CpG}-\mathrm{A}$, -B and $-\mathrm{C}$, respectively) in 24-well culture plates in AIM-V containing $2 \%$ heat-inactivated autologous serum (AS). In some experiments, PBMCs were depleted of PDCs using BDCA4-coupled magnetic beads (Miltenyi Biotec) according to the manufacturer's protocol ( $<0.01 \%$ PDCs identified as $\mathrm{BDCA} 2^{+}$and $\mathrm{CD} 123^{+}$after depletion) to investigate the role of PDCs on the adjuvant effect of
CpG-ODNs. On day 7, the T cells were further stimulated with the peptide-pulsed adherent cells that were cultured with autologous irradiated PBMCs for $4 \mathrm{~h}$. The cytotoxic activity of CTLs was tested against peptide-pulsed A24-LCL cells on day 14 as indicated.

Induction of LY6K peptide-specific CTLs. Monocyte-derived dendritic cells (DCs) were used as antigen-presenting cells to induce CTLs against peptides presented on HLA. DCs were generated in vitro as previously described (18). Briefly, PBMCs isolated from healthy volunteers (HLA-A*2402) were separated by adherence to a plastic tissue culture dish (BectonDickinson) so as to enrich them for the monocyte fraction. The monocyte-enriched population was cultured in the presence of 1,000 U/ml GM-CSF (Kirin) and $500 \mathrm{U} / \mathrm{ml} \mathrm{IL-4} \mathrm{(Ono)} \mathrm{in}$ AIM-V containing $2 \%$ heat-inactivated AS. After 5 days in the culture, TNF- $\alpha(10 \mathrm{ng} / \mathrm{ml}), \mathrm{IL}-6(1,000 \mathrm{U} / \mathrm{ml}), \mathrm{IL}-1 \beta(10 \mathrm{ng} / \mathrm{ml})$ and PGE2 $(1 \mu \mathrm{g} / \mathrm{ml})$ were added to the culture to mature DCs. After 7 days, DCs were pulsed with $20 \mu \mathrm{g} / \mathrm{ml}$ of the synthesized peptides in the presence of $3 \mu \mathrm{g} / \mathrm{ml} \beta 2$-microglobulin (Sigma), pulsed on the cytokine-generated DCs for $4 \mathrm{~h}$ at $37^{\circ} \mathrm{C}$ in AIM-V. These peptide-pulsed DCs were then inactivated by $\gamma$ irradiation (50 Gy) and used as stimulator cells. To increase the precursor frequency of peptide-specific cells, $\mathrm{CD}^{+} \mathrm{T}$ cells were enriched by one round of positive selection using anti-CD8 antibody beads and MACS technology according to the manufacturer's protocol (Miltenyi Biotec; Bergisch-Gladbach, Germany). Then, $\mathrm{CD}^{+} \mathrm{T}$ cells and unseparated PBMCs were mixed at a 1:2 ratio and used as the responder cells. These cultures were set up in 48-well plates (Corning); each well contained $5 \times 10^{4}$ stimulator cells and $1.5 \times 10^{6}$ responder cells in the presence of CpG-ODNs in $0.5 \mathrm{ml}$ of AIM-V/2\% AS. In some experiments, PBMCs were depleted of PDCs using BDCA4-coupled magnetic beads (Miltenyi Biotec) according to the manufacturer's protocol. Two days later, these cultures were supplemented with IL-2 to a final concentration of $20 \mathrm{IU} / \mathrm{ml}$. On day 7 , the T cells were further re-stimulated with the autologous peptide-pulsed DCs. The peptide-pulsed DCs were prepared in the same manner as described above. CTL activity was tested against peptide-pulsed A24-LCL cells on day 14 as indicated.

Cytotoxicity assay. Target cells were labeled with $100 \mu \mathrm{Ci}$ of $\mathrm{Na}_{2}{ }^{51} \mathrm{CrO}_{4}$ (Perkin-Elmer Life Sciences) for $1 \mathrm{~h}$ at $37^{\circ} \mathrm{C}$ in a $\mathrm{CO}_{2}$ incubator. Peptide-pulsed targets were prepared by incubating the cells with $20 \mu \mathrm{g} / \mathrm{ml}$ of the peptide for $16 \mathrm{~h}$ at $37^{\circ} \mathrm{C}$ before labeling. Labeled target cells were rinsed and mixed with effector cells in a final volume of $0.2 \mathrm{ml}$ in roundbottom microtiter plates. The plates were centrifuged (4 min at $800 \mathrm{x} \mathrm{g}$ ) to increase cell-to-cell contact and placed in a $\mathrm{CO}_{2}$ incubator at $37^{\circ} \mathrm{C}$. After $4 \mathrm{~h}$ of incubation, $0.1 \mathrm{ml}$ of the supernatant was collected from each well and the radioactivity was determined with a $\gamma$ counter. The percentage of specific cytotoxicity was determined by calculating the percentage of ${ }^{51} \mathrm{Cr}$ release in $4 \mathrm{~h}$ using the following formula: [( $\mathrm{cpm}$ of the test sample release - cpm of the spontaneous release)/(cpm of the maximum release - cpm of the spontaneous release)] x 100. Spontaneous release was determined by incubating the target cells alone, in the absence of effector cells, and the maximum release was obtained by incubating the targets with $1 \mathrm{~N} \mathrm{HCl}$. All measurements were carried out in triplicate and the standard 
IFN- $\alpha$

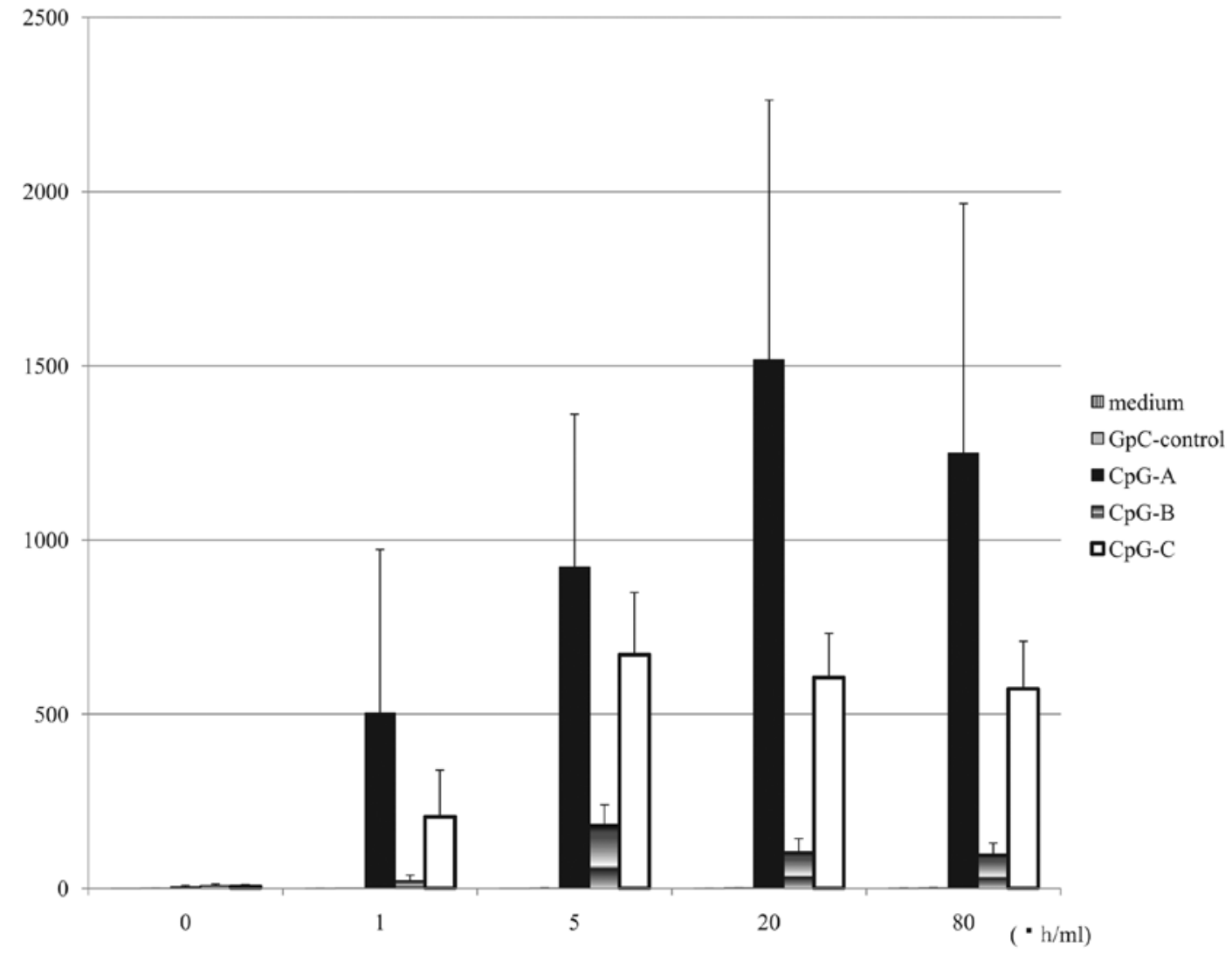

Figure 1. IFN- $\alpha$ secretion from PBMCs stimulated by CpG-ODNs. Levels of IFN- $\alpha$ secreted by PBMC from healthy donors (n=15) after 48-h culture with media, GpC control ODN, A-Class, B-Class or C-Class CpG (all ODN at $0,1,5,20,80 \mu \mathrm{g} / \mathrm{ml}$ ). Bars show mean values and standard error of the means for each group of subjects.

errors of the means were consistently below $10 \%$ of the value of the mean.

Flow cytometric immunofluorescence analysis. Monoclonal antibodies against human CD8PerCP, CD45RAFITC and CCR7PE were purchased from BD Biosciences Pharmingen (Franklin Lakes, NJ, USA). Cells were incubated with specific antibodies in PBS for $30 \mathrm{~min}$ at $4^{\circ} \mathrm{C}$, then analyzed using a FACSCalibur with the Cell Quest software package (BectonDickinson).

\section{Results}

IFN- $\alpha$ secretion from PBMCs stimulated by $C p G-O D N s$. Distinct ODN classes were studied for their ability to stimulate human PBMCs to secrete IFN- $\alpha$. Consistent with previous reports (15-17), IFN- $\alpha$ secretion from PBMCs was greatest with $\mathrm{CpG}-\mathrm{A}$, and it was moderate with $\mathrm{CpG}-\mathrm{C}$; it was lowest with CpG-B. The dosages of CPG-A, B and C that induced the maximum level of IFN- $\alpha$ were 20,5 and $5 \mu \mathrm{g} / \mathrm{ml}$, respectively (Fig. 1).

The effect of CpG-ODNs on the induction of the influenza peptide-specific CTL. The flu peptide-specific CTLs showed clear cytotoxicity against flu peptide-pulsed A24+LCL but not against HIV peptide-pulsed A24+LCL (Fig. 2A and B). The cytotoxicity against flu peptide-pulsed A24+LCL was augmented in the presence of $\mathrm{CpG}-\mathrm{A},-\mathrm{B}$ and $-\mathrm{C}$ but not in the presence of control ODN, and the augmenting effect was greatest with $\mathrm{CpG}-\mathrm{A}$; it was moderate with $\mathrm{CpG}-\mathrm{C}$ and low with CpG-B (Fig. 2A). The depletion of PDCs from PBMCs before stimulation with peptide and $\mathrm{CpG}-\mathrm{ODNs}$ completely abrogated the augmenting effect of each class of CpG-ODN (Fig. 2C-E). These data indicated that the stimulation of PDCs by $\mathrm{CpG}-\mathrm{ODN}$ augmented the expansion and activation of flu peptide-specific CTL to increase the specific cytotoxicity.

Flow cytometric analysis showed the population of $\mathrm{CD}^{+}$ cells in flu peptide-specific CTLs. Interestingly, the subpopulation of effector-memory cells in $\mathrm{CD}^{+}$cells was most increased with CpG-A, and moderately increased with CpG-C (Fig. 3).

CpG-A augmented the LY6K peptide-specific CTL induction in a PDC-dependent manner. The population of LY6K peptide-specific CTL precursor cells in healthy volunteers may be much smaller than that of flu peptide-specific CTLs because LY6K is a cancer-testis antigen (19). Therefore, we investigated whether CpG-ODNs could also affect the induction of LY6K-specific CTLs. Although the induction of influenzaspecific CTL was augmented by all types of CpG-ODN (Fig. 2A), the LY6K peptide-specific CTLs were induced only with $\mathrm{CpG}-\mathrm{A}$ from both donors 1 and 2, but not with CpG-B or CpG-C (Fig. 4A-D). Depletion of PDCs from PBMCs of donor 2 before stimulation with peptide and $\mathrm{CpG}-\mathrm{A}$ completely abrogated the effect of CpG-A (Fig. 4E). 
A. Target : Flu peptide pulsed A24+ LCL

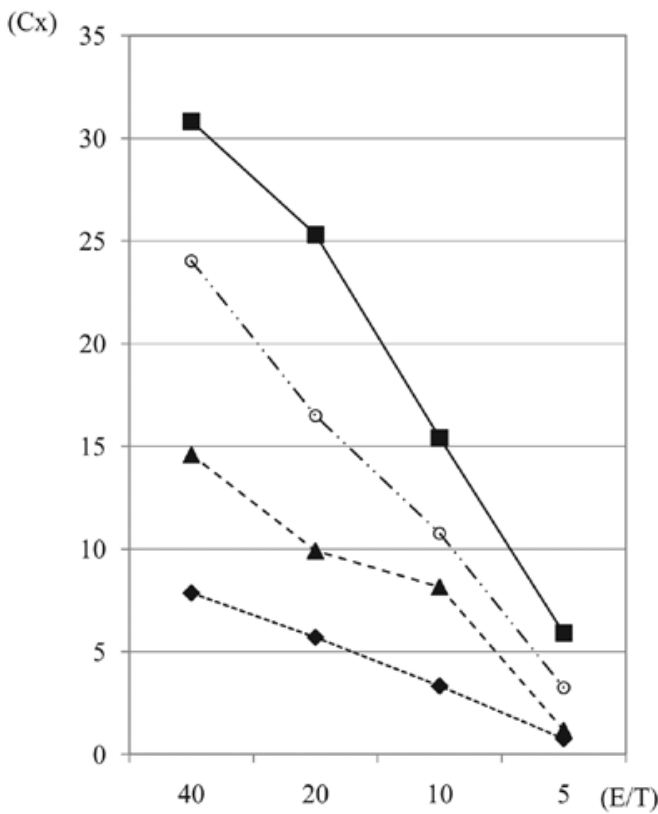

B. Target : HIV peptide pulsed A24+LCL

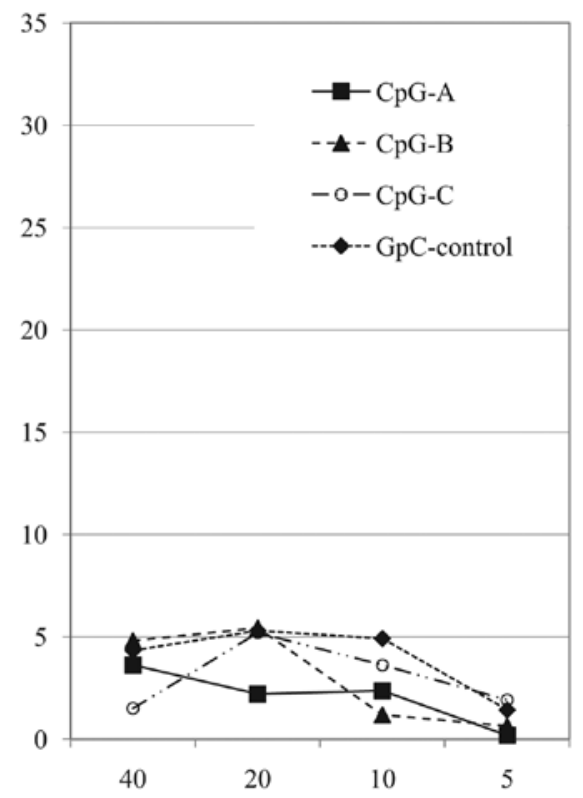

C.

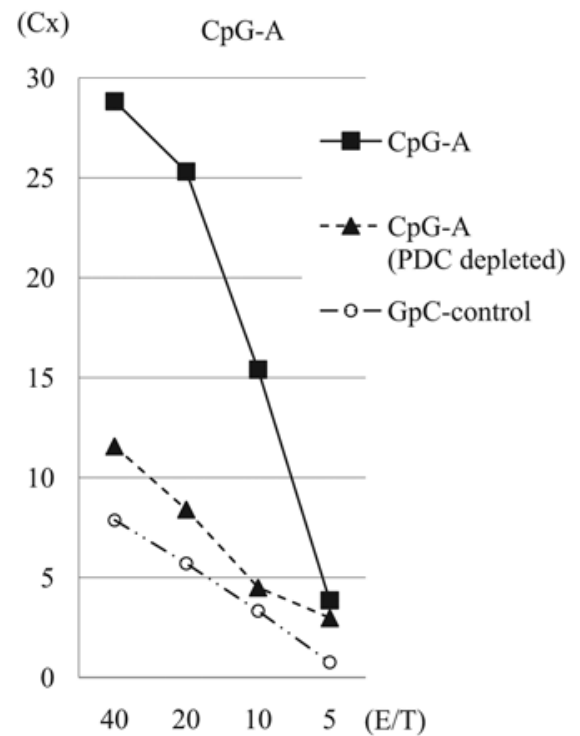

D.
E.

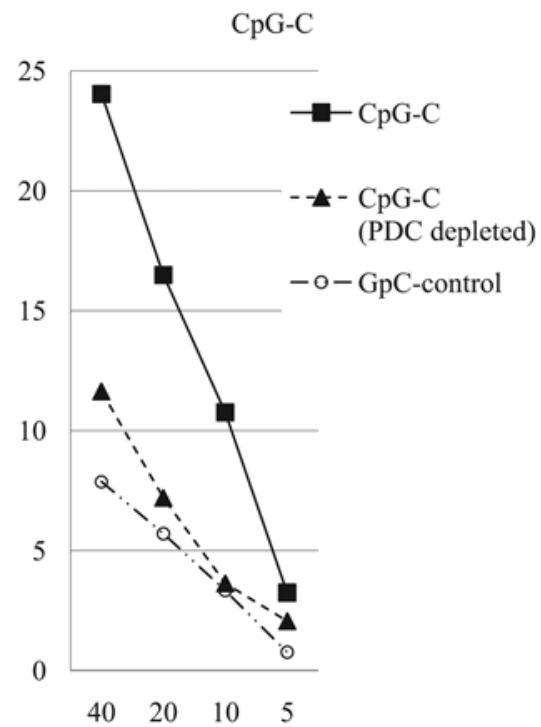

Figure 2. CpG-ODNs augments the influenza peptide-specific CTL induction in a PDC-dependent manner. PBMCs from HLA-A24-positive healthy volunteers were stimulated with the flu peptide in the presence or absence of each class of CpG-ODN $(20,5$ and $5 \mu \mathrm{g} / \mathrm{ml}$ for CpG-A, -B and -C, respectively). After 7 days, effector cells were harvested and re-stimulated with the flu peptide pulsed on adherent cells of irradiated PBMCs. After another 7 days, the cytotoxicity of harvested cells against the HLA-A24-positive LCL-A24 cell line pulsed with the flu peptide (A) or a control HIV peptide (B) was assessed by standard ${ }^{51} \mathrm{Cr}$ release assay. Data shown are representative of three independent experiments. PDCs were depleted from PBMCs on day 0. After stimulation with peptide and CpG-ODNs, harvested cells were assessed by standard ${ }^{51} \mathrm{Cr}$ release assay in the same way (C-E).

These data indicated that the stimulation of PDCs by CpG-A augmented the expansion and activation of LY6K peptidespecific $\mathrm{CD}^{+} \mathrm{T}$ cells.

\section{Discussion}

Recently, dozens of clinical trials of vaccine therapy for infectious diseases or cancers using $\mathrm{CpG}-\mathrm{ODNs}$ as an adjuvant have been performed, and some of these trials have shown promising results (5-8). In contrast, there have been few studies that showed the augmenting effects of $\mathrm{CpG}-\mathrm{ODNs}$ on acquired immunity as a vaccine adjuvant (20). Therefore, the mechanism by which CpG-ODNs augment the efficiency of a vaccine has yet to be clarified in sufficient detail.

In the present study, the efficiency of in vitro flu peptidespecific CTL induction by flu peptide was enhanced in the presence of each type of $\mathrm{CpG}-\mathrm{ODN}$, and $\mathrm{CpG}-\mathrm{A}$ showed a more potent adjuvant effect than $\mathrm{CpG}-\mathrm{B}$ and $\mathrm{CpG}-\mathrm{C}$. Moreover, the 
CD8+ cells

GpC-control

CpG-C
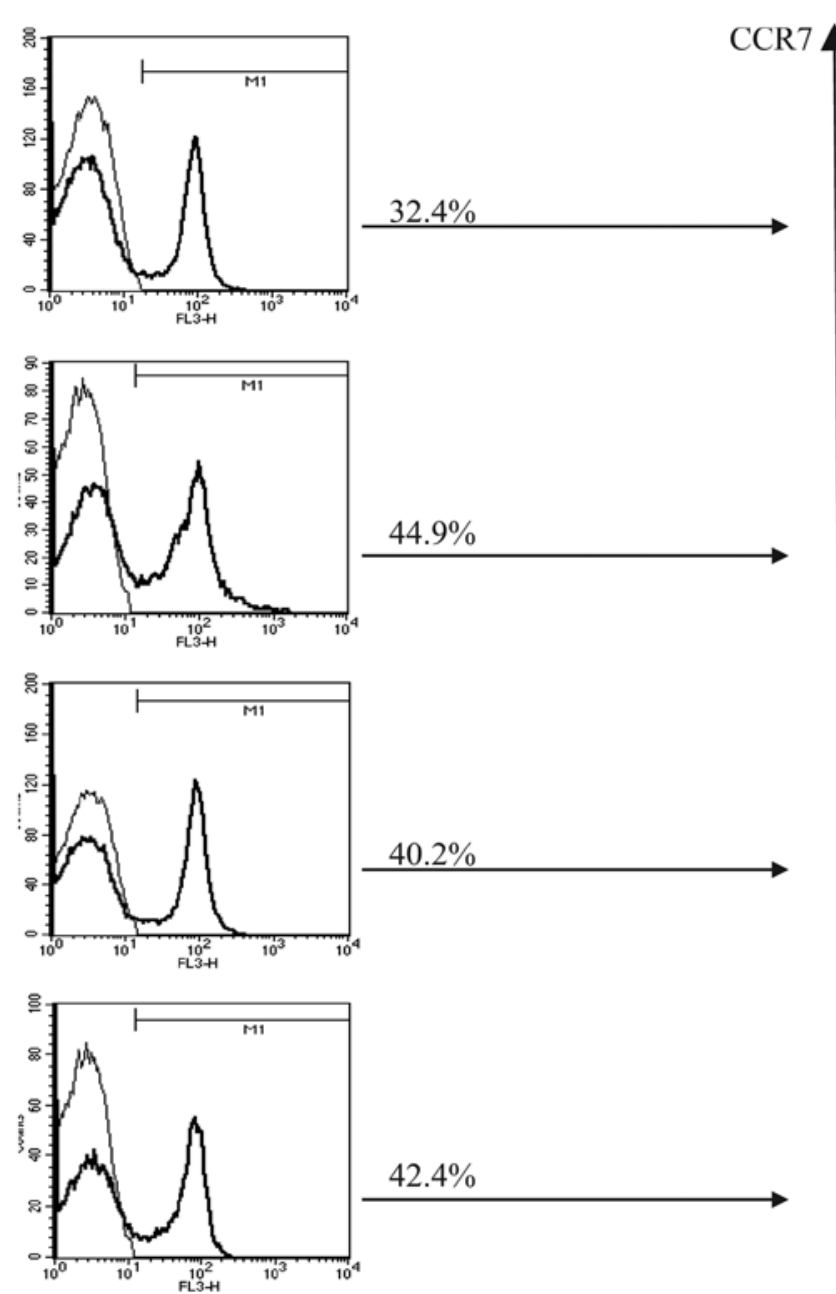

CCR7-CD45RA- cells in CD8+ cells

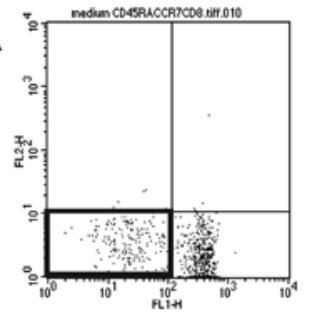

$23.9 \%$

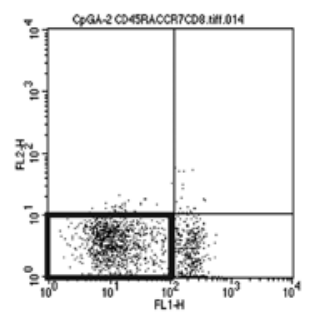

$72.2 \%$

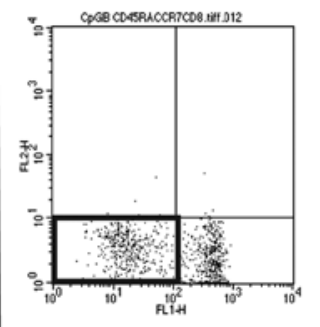

$44.5 \%$

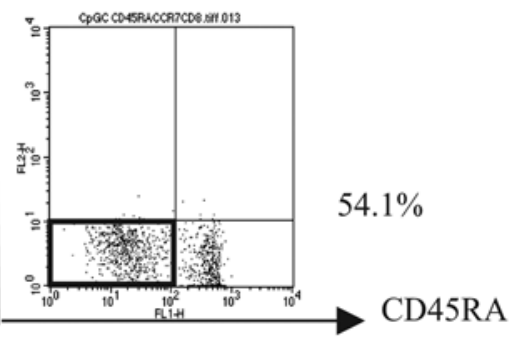

Figure 3. The subpopulation of effector-memory cells in $\mathrm{CD}^{+}$cells was increased with CpG-ODN. Populations of CD8 ${ }^{+}$cells in harvested cells and CCR7CD45RA ${ }^{-}$effector-memory $\mathrm{T}$ cells among $\mathrm{CD} 8^{+}$cells were assessed by flow cytometry.

Ly6K peptide-specific cytotoxicity was induced only with the coexistence of CpG-A, but not with CpG-B and CpG-C. It was suggested that the stimulation of $\mathrm{CpG}-\mathrm{B}$ or $\mathrm{CpG}-\mathrm{C}$ was insufficient to elicit Ly6K peptide-specific CTLs because the number of Ly6K peptide-specific precursor CTLs in healthy volunteers is much smaller than that of flu peptide-specific precursor CTLs. These data suggested that CpG-A might be more effective than $\mathrm{CpG}-\mathrm{B}$ or $\mathrm{CpG}-\mathrm{C}$ in terms of inducing peptide-specific CTLs in vitro.

Our data showed that this CpG-ODN-induced enhancement of cytotoxicity completely disappeared when PDCs were depleted from PBMCs, which means that PDCs were responsible for this enhancement effect. CpG-ODNs mature PDCs by up-regulating the expression of CD80, CD83 and CD86 (21). While most studies have indicated that MoDCs are better antigen-presenters than PDCs (22), many studies have demonstrated the ability of PDCs to function as APCs for both CD4- and CD8-positive cells (22-24). On the other hand, it is well known that $\mathrm{CpG}-\mathrm{B}$ and $\mathrm{CpG}-\mathrm{C}$ are more potent to mature PDCs than CpG-A $(1,2)$. Because our data showed that $\mathrm{CpG}-\mathrm{A}$ was superior to $\mathrm{CpG}-\mathrm{B}$ and $\mathrm{CpG}-\mathrm{C}$ in inducing peptide-specific CTLs, the maturation of PDCs by the stimulation of CpG-ODNs could not affect the results in view of our study design. Therefore, we considered that any cytokines produced from PDCs stimulated by $\mathrm{CpG-ODNs}$ must contribute to the enhancement of peptide-specific CTL induction. In addition to IFNs, PDCs also produced the pro-inflammatory cytokines TNF- $\alpha$ and IL-6 (data not shown). Type-1 IFN, TNF- $\alpha$ and IL-6 are known to drive the differentiation of DCs into mature antigen-presentation cells. Our data also showed that the supernatant of PBMCs stimulated by $\mathrm{CpG-ODNs} \mathrm{up-regulated} \mathrm{the}$ expression of CD80, 83 and 86 on monocyte-derived DCs, and the expression level was highest with $\mathrm{CpG}-\mathrm{A}$, less with CpG-C, and least with CpG-B (data not shown). However, the production levels of TNF- $\alpha$ and IL- 6 from PBMCs stimulated by $\mathrm{CpG}-\mathrm{A}$ were almost the same as those for $\mathrm{CpG}-\mathrm{B}$ and CpG-C. Murine PDCs are known to produce IL-12, which induces Th1 differentiation by the stimulation of CpG-ODNs, but human PDCs do not induce IL-12 (25,26). In contrast, CpG-A produced a much higher level of IFN- $\alpha$ than CpG-B or CpG-C, and we considered that the reason why $\mathrm{CpG}-\mathrm{A}$ has the most potent augmenting effect to induce peptide-specific CTLs is that CpG-A induces the highest level of type-1 IFN from PDCs. 
Donor 1 A. Target : Ly6K peptide pulsed A24+ LCL

B. Target : HIV peptide pulsed A24+LCL
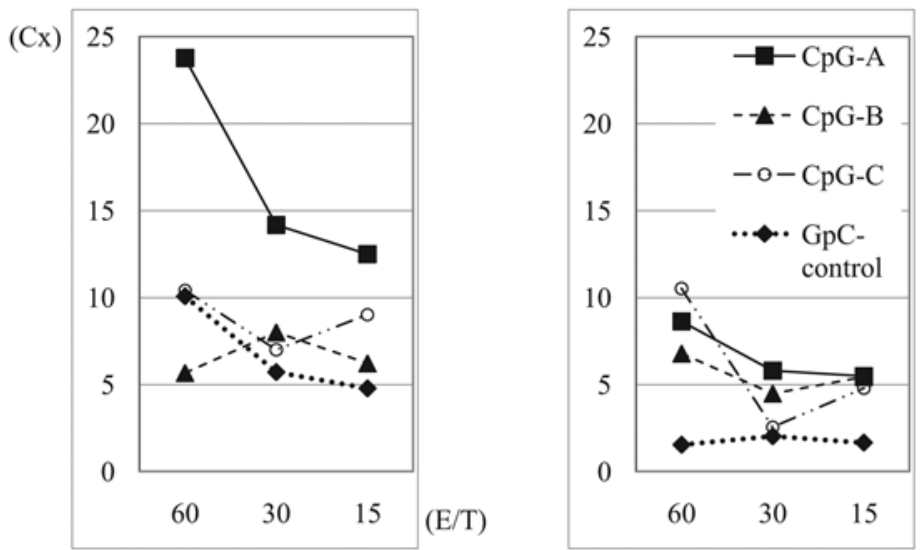

Donor 2 C. Target : Ly6K peptide pulsed A24+ LCL

D. Target : HIV peptide pulsed A24+LCL

E. Target : Ly6K peptide pulsed A24+LCL
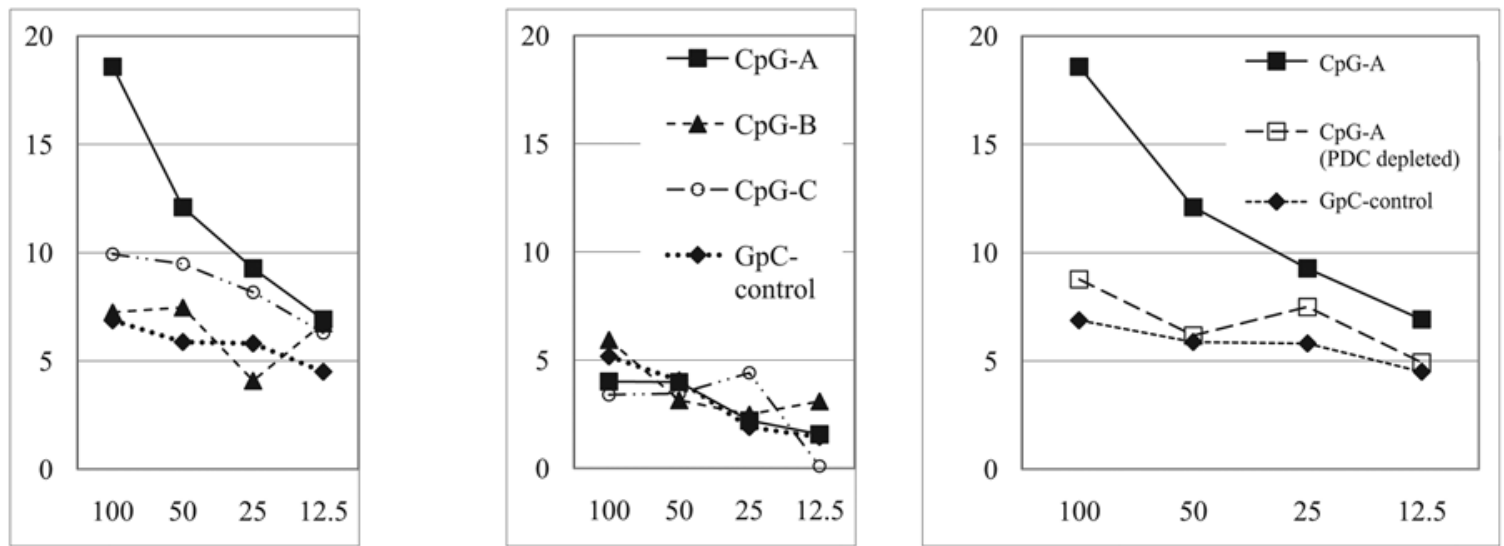

Figure 4. CpG-A augments the Ly6K peptide-specific CTL induction in a PDC-dependent manner. LY6K peptide-specific CTL was generated from 2 different donors in the presence or absence of each class of CpG-ODN (20,5 and $5 \mu \mathrm{g} / \mathrm{ml}$ for CpG-A, -B and -C, respectively) as described in Materials and methods. The cytotoxicity of harvested cells against the HLA-A24-positive LCL-A24 cell line pulsed with the LY6K peptide (A and C) or a control HIV peptide (B and D) was assessed by standard ${ }^{51} \mathrm{Cr}$ release assay. PDCs were depleted from PBMCs on day 0. After stimulation with peptide and CpG-A, harvested cells were assessed by standard ${ }^{51} \mathrm{Cr}$ release assay in the same way $(\mathrm{E})$.

Type-1 IFNs are known to activate NK cells $(27,28)$ and induce activation of DCs (29-32). In murine models, it is known that type-1 IFNs promote Th1 cytokine production, effector differentiation, proliferation and contribute to the clonal expansion and formation of memory CD8 ${ }^{+} \mathrm{T}$ cells (33-40).

Our data revealed that the population of $\mathrm{CD} 8^{+}$cells and that of effector-memory cells in $\mathrm{CD} 8^{+}$cells after induction of flu peptide-specific CTLs were increased the most with CpG-A, less with CpG-C and least with CpG-B. Memory cells persist for extended periods owing to antigen-independent homeostatic turnover and they respond rapidly upon re-encountering a pathogen (41). Two subsets of memory $\mathrm{T}$ cells were described on the basis of their anatomical location, expression of cell surface markers and effector functions (42). Memory T cells that express molecules such as CCR7, which allow efficient homing to lymph nodes (LN), are termed central memory cells $\left(\mathrm{T}_{\mathrm{CM}}\right)$, whereas memory $\mathrm{T}$ cells that lack expression of these $\mathrm{LN}$ homing receptors and are located in no lymphoid tissues are termed effector memory cells $\left(\mathrm{T}_{\mathrm{EM}}\right)$. Some studies have also shown that $\mathrm{T}_{\mathrm{EM}}$ acquire effector functions, such as cytokine production and killing, more rapidly than $\mathrm{T}_{\mathrm{CM}}$ (42-44). The mechanisms that contribute to the generation of memory cells are poorly understood. Previous studies suggested that infectious antigen-experienced $\mathrm{CD} 8^{+} \mathrm{T}$ cells undergo programmed expansion for about 1 week after infection and then undergo programmed cell death (45-47). A majority of the daughter cells derived from antigen-experienced $\mathrm{CD} 8^{+} \mathrm{T}$ cells undergo death in parallel with proliferation during the acute phase of viral infection and direct type-I IFN action rescues them from this death, thereby tilting the balance effectively toward clonal expansion (40). Therefore, the type-I IFN-mediated rescue from death during antigen-driven proliferation might be critical for the expansion of memory precursors.

In conclusion, our data showed that the stimulation of PDCs by CpG-ODN augmented the generation of effectormemory peptide-specific CTLs. Furthermore, CpG-A might be superior to $\mathrm{CpG}-\mathrm{B}$ and $\mathrm{CpG}-\mathrm{C}$ in augmenting the generation of human peptide-specific CTLs in vitro. Therefore, CpG-A could become a superior vaccine adjuvant rather than $\mathrm{CpG}-\mathrm{B}$ or $\mathrm{CpG}-\mathrm{C}$ in clinical application.

\section{References}

1. Klinman DM: Immunotherapeutic uses of $\mathrm{CpG}$ oligodeoxynucleotides. Nat Rev Immunol 4: 249-258, 2004. 
2. Krieg AM: Therapeutic potential of Toll-like receptor 9 activation. Nat Rev Drug Discov 5: 471-484, 2006.

3. Janeway CA Jr: Approaching the asymptote? Evolution and revolution in immunology. Cold Spring Harb Symp Quant Biol 54: 1-13, 1989.

4. Marrack P and Kappler J: Subversion of the immune system by pathogens. Cell 76: 323-332, 1994.

5. Speiser DE, Lienard D, Rufer N, Rubio-Godoy V, Rimoldi D, Lejeune F, Krieg AM, Cerottini JC and Romero P: Rapid and strong human $\mathrm{CD} 8^{+} \mathrm{T}$ cell responses to vaccination with peptide, IFA, and CpG oligodeoxynucleotide 7909. J Clin Invest 115 739-746, 2005.

6. Valmori D, Souleimanian NE, Tosello V, Bhardwaj N, Adams S, O'Neill D, Pavlick A, Escalon JB, Cruz CM, Angiulli A, Angiulli F, Mears G, Vogel SM, Pan L, Jungbluth AA, Hoffmann EW, Venhaus R, Ritter G, Old LJ and Ayyoub M: Vaccination with NY-ESO-1 protein and CpG in Montanide induces integrated antibody/Th1 responses and CD8 T cells through cross-priming. Proc Natl Acad Sci USA 104: 8947-8952, 2007.

7. Karbach J, Gnjatic S, Bender A, Neumann A, Weidmann E, Yuan J, Ferrara CA, Hoffmann E, Old LJ, Altorki NK and Jäger E: Tumor-reactive CD8 ${ }^{+}$T-cell responses after vaccination with NY-ESO-1 peptide, CpG 7909 and Montanide ISA-51: association with survival. Int J Cancer 126: 909-918, 2010.

8. Fourcade J, Kudela P, Andrade Filho PA, Janjic B, Land SR, Sander C, Krieg A, Donnenberg A, Shen H, Kirkwood JM and Zarour HM: Immunization with analog peptide in combination with $\mathrm{CpG}$ and montanide expands tumor antigen-specific $\mathrm{CD}^{+} \mathrm{T}$ cells in melanoma patients. J Immunother 31: 781-791, 2008

9. Krieg AM: Antiinfective applications of toll-like receptor 9 agonists. Proc Am Thorac Soc 4: 289-294, 2007.

10. Liu YJ: IPC: professional type 1 interferon-producing cells and plasmacytoid dendritic cell precursors. Annu Rev Immunol 23 : 275-306, 2005.

11. Bauer S, Kirschning CJ, Hacker H, Redecke V, Hausmann S, Akira S, Wagner $\mathrm{H}$ and Lipford GB: Human TLR9 confers responsiveness to bacterial DNA via species-specific CpG motif recognition. Proc Natl Acad Sci USA 98: 9237-9242, 2001.

12. Kadowaki N, Ho S, Antonenko S, Malefyt RW, Kastelein RA, Bazan F and Liu YJ: Subsets of human dendritic cell precursors express different Toll-like receptors and respond to different microbial antigens. J Exp Med 194: 863-869, 2001

13. Vollmer J, Jurk M, Samulowitz U, Lipford G, Forsbach A Wüllner M, Tluk S, Hartmann H, Kritzler A, Müller C, Schetter C and Krieg AM: CpG oligodeoxynucleotides stimulate IFN-gammainducible protein-10 production in human B cells. J Endotoxin Res 10: 431-438, 2004.

14. Hornung V, Rothenfusser S, Britsch S, Krug A, Jahrsdorfer B, Giese T, Endres S and Hartmann G: Quantitative expression of Toll-like receptor 1-10 mRNA in cellular subsets of human peripheral blood mononuclear cells and sensitivity to $\mathrm{CpG}$ oligodeoxynucleotides. J Immunol 168: 4531-4537, 2002.

15. Krieg AM: Antitumor applications of stimulating toll-like receptor 9 with $\mathrm{CpG}$ oligodeoxynucleotides. Curr Oncol Rep 6 : $88-95,2004$

16. Martinson JA, Tenorio AR, Montoya CJ, Al-Harthi L, Gichinga CN, Krieg AM, Baum LL and Landay AL: Impact of class $\mathrm{A}, \mathrm{B}$ and $\mathrm{C} \mathrm{CpG}$-oligodeoxynucleotides on in vitro activation of innate immune cells in human immunodeficiency virus-1 infected individuals. Immunology 120: 526-535, 2007.

17. Marshall JD, Fearon K, Abbate C, Subramanian S, Yee P, Gregorio J, Coffman RL and van Nest G: Identification of a novel CpG DNA class and motif that optimally stimulate B cell and plasmacytoid dendritic cell functions. J Leukoc Biol 73 : 781-792, 2003

18. Tanaka H, Tsunoda T, Nukaya I, Sette A, Matsuda K, Umano Y, Yamaue $\mathrm{H}$, Takesako $\mathrm{K}$ and Tanimura $\mathrm{H}$ : Mapping the HLA-A24-restricted T-cell epitope peptide from a tumor-associated antigen HER2/neu: possible immunotherapy for colorectal carcinomas. Br J Cancer 84: 94-99, 2001.

19. Ishikawa N, Takano A, Yasui W, Inai K, Nishimura H, Ito $H$ Miyagi Y, Nakayama H, Fujita M, Hosokawa M, Tsuchiya E, Kohno N, Nakamura Y and Daigo Y: Cancer-testis antigen lymphocyte antigen 6 complex locus $\mathrm{K}$ is a serologic biomarker and a therapeutic target for lung and esophageal carcinomas. Cancer Res 67: 11601-11611, 2007.
20. Rothenfusser S, Hornung V, Ayyoub M, Britsch S, Towarowski A, Krug A, Sarris A, Lubenow N, Speiser D, Endres S and Hartmann G: CpG-A and CpG-B oligonucleotides differentially enhance human peptide-specific primary and memory CD8 T-cell responses in vitro. Blood 103: 2162-2169, 2004.

21. Fitzgerald-Bocarsly P, Dai J and Singh S: Plasmacytoid dendritic cells and type I IFN: 50 years of convergent history. Cytokine Growth Factor Rev 19: 3-19, 2008.

22. Grouard G, Rissoan MC, Filgueira L, Durand I, Banchereau J and Liu YJ: The enigmatic plasmacytoid T cells develop into dendritic cells with interleukin (IL)-3 and CD40-ligand. J Exp Med 185: 1101-1111, 1997.

23. Cella M, Jarrossay D, Facchetti F, Alebardi O, Nakajima H, Lanzavecchia A and Colonna M: Plasmacytoid monocytes migrate to inflamed lymph nodes and produce large amounts of type I interferon. Nat Med 5: 919-923, 1999.

24. Niessner A, Sato K, Chaikof EL, Colmegna I, Goronzy JJ and Weyand CM: Pathogen-sensing plasmacytoid dendritic cells stimulate cytotoxic T-cell function in the atherosclerotic plaque through interferon-alpha. Circulation 114: 2482-2489, 2006.

25. Krug A, Towarowski A, Britsch S, Rothenfusser S, Hornung V, Bals R, Giese T, Engelmann H, Endres S, Krieg AM and Hartmann G: Toll-like receptor expression reveals CpG DNA as a unique microbial stimulus for plasmacytoid dendritic cells which synergizes with CD40 ligand to induce high amounts of IL-12. Eur J Immunol 31: 3026-3037, 2001.

26. Dzionek A, Inagaki Y, Okawa K, Nagafune J, Röck J, Sohma Y, Winkels G, Zysk M, Yamaguchi Y and Schmitz J: Plasmacytoid dendritic cells: from specific surface markers to specific cellular functions. Hum Immunol 63: 1133-1148, 2002.

27. Trinchieri G, Santoli D, Dee RR and Knowles BB: Anti-viral activity induced by culturing lymphocytes with tumor-derived or virus-transformed cells. Identification of the anti-viral activity as interferon and characterization of the human effector lymphocyte subpopulation. J Exp Med 147: 1299-1313, 1978.

28. Bandyopadhyay S, Perussia B, Trinchieri G, Miller DS and Starr SE: Requirement for HLA-DR ${ }^{+}$accessory cells in natural killing of cytomegalovirus-infected fibroblasts. J Exp Med 164: 180-195, 1986.

29. Luft T, Pang KC, Thomas E, Hertzog P, Hart DN, Trapani J and Cebon J: Type I IFNs enhance the terminal differentiation of dendritic cells. J Immunol 161: 1947-1953, 1998.

30. Biron CA: Interferons alpha and beta as immune regulators - a new look. Immunity 14: 661-664, 2001.

31. Le Bon A, Etchart N, Rossmann C, Ashton M, Hou S, Gewert D, Borrow P and Tough DF: Cross-priming of $\mathrm{CD} 8^{+} \mathrm{T}$ cells stimulated by virus-induced type I interferon. Nat Immunol 4: 1009-1015, 2003.

32. Krug A, Veeraswamy R, Pekosz A, Kanagawa O, Unanue ER, Colonna $\mathrm{M}$ and Cella $\mathrm{M}$ : Interferon-producing cells fail to induce proliferation of naive $\mathrm{T}$ cells but can promote expansion and $T$ helper 1 differentiation of antigen-experienced unpolarized T cells. J Exp Med 197: 899-906, 2003.

33. Cella M,Facchetti F, Lanzavecchia A and Colonna M: Plasmacytoid dendritic cells activated by influenza virus and CD40L drive a potent TH1 polarization. Nat Immunol 1: 305-310, 2000.

34. Parronchi P, De Carli M, Manetti R, Simonelli C, Sampognaro S, Piccinni MP, Macchia D, Maggi E, Del Prete G and Romagnani S: IL-4 and IFN (alpha and gamma) exert opposite regulatory effects on the development of cytolytic potential by Th1 or Th2 human T cell clones. J Immunol 149: 2977-2983, 1992.

35. Wenner CA, Guler ML, Macatonia SE, O'Garra A and Murphy KM: Roles of IFN-gamma and IFN-alpha in IL-12-induced T helper cell-1 development. J Immunol 156: 1442-1447, 1996.

36. Marrack P, Kappler J and Mitchell T: Type I interferons keep activated T cells alive. J Exp Med 189: 521-530, 1999.

37. Nguyen KB, Watford WT, Salomon R, Hofmann SR, Pien GC, Morinobu A, Gadina M, O'Shea JJ, and Biron CA: Critical role for STAT4 activation by type 1 interferons in the interferon-gamma response to viral infection. Science 297: 2063-2066, 2002

38. Marrack P and Kappler J: Control of T cell viability. Annu Rev Immunol 22: 765-787, 2004.

39. Curtsinger JM, Valenzuela JO, Agarwal P, Lins D and Mescher MF: Cutting edge: type I IFNs provide a third signal to CD8 T cells to stimulate clonal expansion and differentiation. J Immunol 174: 4465-4469, 2005 
40. Kolumam GA, Thomas S, Thompson LJ, Sprent J and Murali-Krishna K: Type I interferons act directly on CD8 T cells to allow clonal expansion and memory formation in response to viral infection. J Exp Med 202: 637-650, 2005.

41. Kaech SM, Wherry EJ and Ahmed R: Effector and memory T-cell differentiation: implications for vaccine development. Nat Rev Immunol 2: 251-262, 2002.

42. Sallusto F, Lenig D, Forster R, Lipp M and Lanzavecchia A: Two subsets of memory $\mathrm{T}$ lymphocytes with distinct homing potentials and effector functions. Nature 401: 708-712, 1999.

43. Masopust D, Vezys V, Marzo AL and Lefrancois L: Preferential localization of effector memory cells in nonlymphoid tissue. Science 291: 2413-2417, 2001.
44. Reinhardt RL, Khoruts A, Merica R, Zell T and Jenkins MK: Visualizing the generation of memory CD4 T cells in the whole body. Nature 410: 101-105, 2001.

45. Tanchot C, Lemonnier F, Perarnau B, Freitas A and Rocha B: Differential requirements for survival and proliferation of CD8 naive or memory cells. Science 276: 2057-2062, 1997.

46. Ku CC, Murakami M, Sakamoto A, Kappler J and Marrack P: Control of homeostasis of $\mathrm{CD}^{+}$memory $\mathrm{T}$ cells by opposing cytokines. Science 288: 675-678, 2000.

47. Schluns KS, Kieper WC, Jameson SC and Lefrancois L: Interleukin-7 mediates the homeostasis of naive and memory CD8 T cells in vivo. Nat Immunol 1: 426-432, 2000. 